\title{
Broccoli yield in response to top-dressing fertilization with green manure and biofertilizer
}

\author{
Gilberto Bernardo de Freitas ${ }^{1}$, Márcio Sousa Rocha ${ }^{2}$, Ricardo Henrique Silva Santos ${ }^{1}$ \\ Letícia Monteiro da Silva Freitas ${ }^{3}$, Leandro de Almeida Resende ${ }^{3}$
}

\begin{abstract}
The objective of this work was to evaluate the productive performance of broccoli under different top-dressing organic fertilizations. The experiment was conducted under protected cultivation, in a completely randomized design with four replications, with two plants per experimental unit. Broccoli seedlings were produced in a commercial substrate in styrofoam trays. The seedlings were transplanted to plastic pots containing $10.0 \mathrm{~L}$ of substrate made up of subsoil and organic compost at the ratio of $3: 1(\mathrm{v} / \mathrm{v})$, respectively, which is equivalent to about $20.0 \mathrm{tha}^{-1}$ of organic compost at planting. After seedling establishment, the top-dressing fertilization treatments were applied: gliricidia biomass associated or not with liquid biofertilizer of cattle manure to the soil and bokashi. Two control treatments were established: one with mineral fertilization recommended for the crop and the other without top-dressing fertilization. The broccoli production was evaluated (commercial standard). Plants that received mineral fertilizer were more productive, however, they were not significantly different ( $p>0.05$ ), by Dunnet test, from the plants fertilized with $2.5 \mathrm{t}$ $\mathrm{ha}^{-1}$ gliricidia biomass (dry mass) associated with liquid biofertilizer $\left(2.0 \mathrm{~L} \mathrm{~m}^{-2}\right)$ applied to soil. Top-dressing fertilizations with only gliricidia, at 2.5 and $5.0 \mathrm{t} \mathrm{ha}^{-1}$ of biomass (dry mass), resulted in no significant increase in production of broccoli inflorescence. The use of bokashi in addition to gliricidia biomass and liquid biofertilizer reduced the efficiency of the fertilization compared with plants that received only gliricidia and liquid biofertilizer.
\end{abstract}

Key words: Organic horticulture, organic fertilization, Gliricidia sepium (Jacq.), biofertilizer; Brassica oleracea L. var. italica.

\section{RESUMO}

\section{Resposta de brócolis à adubação de cobertura com biomassa de adubo verde e biofertilizante}

O objetivo deste trabalho foi avaliar o desempenho produtivo de plantas de brócolis, submetidas a diferentes sistemas de adubação orgânica de cobertura. O experimento foi conduzido em ambiente protegido, em delineamento inteiramente casualizado, com quatro repetições e duas plantas por unidade experimental. Mudas de brócolis, produzidas em bandejas de isopor com substrato comercial, foram transplantadas para vasos plásticos, contendo 10,0 L de substrato formado pela mistura de terra de subsolo e composto orgânico, na proporção de 3:1 (v/v), respectivamente, adubação esta equivalente a cerca de $20,0 \mathrm{t} \mathrm{ha}^{-1}$ de composto, por ocasião do plantio. Após o pegamento das mudas, foram aplicados os tratamentos de adubação de cobertura, baseados na aplicação de biomassa de gliricídia, associada, ou não, à aplicação de biofertilizante líquido de esterco bovino, via solo e a bokashi. Houve dois tratamentos testemunhas: um, sem adubação de cobertura e, outro, com a adubação mineral de cobertura indicada para a cultura. Avaliou-

Recebido para publicação em 15/05/2009 e aprovado em 09/08/2011

${ }^{1}$ Agronomist Engineer, Doctor Science. Departamento de Fitotecnia, Universidade Federal de Viçosa, Av. Peter Henry Rolfs, s/n, 36570-000, Viçosa, Minas Gerais, Brazil. bernardo@ufv.br, rsantos@ufv.br

${ }^{2}$ Agronomist Engineer. Agrodefesa - Agência Goiana de Defesa Agropecuária. Rua Marechal Deodoro, nº 505, Centro, 76170-000, Anicuns, Goiás, Brasil, Brazil. marcio.sousarocha@yahoo.com.br

${ }^{3}$ Agronomist Engineer. Departamento de Fitotecnia, Universidade Federal de Viçosa, Av. Peter Henry Rolfs, s/n, 36570-000, Viçosa, Minas Gerais, Brazil. leticiamsfreitas@gmail.com, leandrodealmeida.s1@ hotmail.com 
se a produção de inflorescências comerciais de brócolis. Plantas que receberam adubações de cobertura com adubos químicos apresentaram-se mais produtivas, entretanto, não diferiram ( $p>0,05)$, pelo teste de Dunnett, de plantas que receberam adubação de cobertura correspondente a $2,5 \mathrm{t} \mathrm{ha}^{-1}$ de biomassa seca de gliricídia , associada à aplicação de biofertilizante líquido de esterco bovino, via solo, na dose de $2,0 \mathrm{~L} \mathrm{~m}^{-2}$. Adubações de cobertura apenas com biomassa de gliricídia, nas doses de 2,5 e 5,0 t ha ${ }^{-1}$ de biomassa seca, não proporcionaram aumentos significativos de produção de inflorescências de brócolis. O uso de bokashi reduziu a eficiência da adubação de cobertura com biomassa de gliricídia associada ao uso de biofertilizante líquido de esterco bovino.

Palavras-chave: Olericultura orgânica, adubação orgânica, Gliricidia sepium (Jacq.), biofertilizante; Brassica oleracea L. var. italica.

\section{INTRODUCTION}

Vegetable crops require large amounts of nutrients broccoli, for example, extracts about $500.0 \mathrm{~kg} \mathrm{ha}^{-1}$ of $\mathrm{N}$ throughout its production cycle. The high nutritional demands associated with the low investment capacity of family farmers have led to inappropriate plant nutrient management and hence low yields. Additionally, the imbalance in the supply of nutrients is a major problem affecting the sustainability of agricultural systems worldwide, both by the insufficient replacement and by the excessive nutrients applied (Vitousek et al. 2009). For this reason, it is important, in a broader view, to promote techniques that contribute to increased input of nutrients, their cycling in agroecosystems and the use of local resources. Alternative fertilization systems that allow the utilization of organic materials available or easily obtainable in the farms are needed to reduce the dependence on mineral fertilizers and increase the rate of organic matter input into areas of production.

The use of animal manure (Lupwayi \& Haque, 1999, Whalen et al. 2001; van Kessel \& Reeves, 2002) and green manure (Palm \& Sanchez, 1991; Handayanto et al., 1997; Cobo et al., 2002) is an alternative to increasing the economic and environmental sustainability especially of small farms. Green manure, in addition to organic compost, can provide adequate amounts of nitrogen to crops, which in part derives from the biological fixation, through the symbiotic association between bacteria and legumes, and also allows the cycling of other nutrients essential to crops. Green manure also provides increased levels of soil organic matter, which makes an important contribution to the cation exchange capacity (CEC) of tropical soils (Raij, 1969), and incorporates organic matter into the soil, through the root systems of plants. Green manures provide soil cover and protection, helping to reduce erosion, and, finally, the plants can also be used as fodder for animal feed.
A study comparing the green manures sunnhemp (Crotalaria juncea L.), black-velvet bean (Stizolobium aterrimum Piper et Tracy) and jackbean (Canavalia ensiformes L. (DC)) with mineral fertilizer and incorporated spontaneous vegetation, in the production of cabbage and crisphead lettuce, showed no significant difference between green manuring and mineral fertilization for production of total fresh mass and commercial fresh mass of lettuce leaves (Fontanetti et al. 2006 ). But, sunnhemp was more efficient than jackbean or black-velvet bean in increasing the commercial weight of cabbage head with production similar to that obtained with the mineral fertilizer. However, the average weight of cabbage heads of all treatments ranged from 1,215.5 $\mathrm{g}$ and $1,960.0 \mathrm{~g}$ (Fontanetti et al., 2006), meeting the Brazilian standard size (between $1,000.0 \mathrm{~g}$ and 1,500.0 $\mathrm{g}$ per head) (Lêdo et al., 2000). Oliveira et al. (2005) working with pre-plant incorporated sunnhemp also obtained average commercial weight of cabbage heads of $1,260.0 \mathrm{~g}$.

Mesquita et al. (2007) reported positive effects of liquid bio-fertilizers applied to the soil on the yield and physicochemical quality of papaya fruits cv. "Baixinho de Santa Amália". Araujo et al. (2008) evaluated the effect of different rates and intervals of application of liquid biofertilizer to the soil on yellow passion fruit, and also reported higher growth rates and larger fruit production in plants that received the treatments.

The effect of unincorporated residues of sorghum, millet, sunnhemp and spontaneous vegetation on the production of broccoli inflorescences was evaluated in a no-tillage system (Silva, 2002). In the first year, plants that were covered with biomass of spontaneous vegetation produced smaller inflorescences than those covered with residues of sorghum, millet and sunnhemp. In the second year, it was evaluated the coverage by residues of sorghum, sorghum and sunnhemp, and spontaneous vegetation. In this evaluation, the biomass of sunnhemp, as well as the treatment that received sunnhemp and 
sorghum provided higher yields than the treatments with only sorghum and spontaneous vegetation (Silva, 2002).

Therefore, this study was conducted to compare different forms of organic fertilization by top-dressing in broccoli cultivation, using low-cost inputs which are generally available or easily obtainable in small farms, such as poultry litter, compost, legume biomass, liquid bio-fertilizer made from fresh cattle manure and Bokashi.

\section{MATERIALS AND METHODS}

The experiment was conducted in a protected environment, the Sector of Fruit Crops, Federal University of Viçosa (UFV).

Broccoli seedlings, cv. Ramoso Santana, were produced in a commercial substrate in polystyrene trays. The seedlings ( $5 \mathrm{~cm}$ tall) were transplanted to plastic pots containing $10.0 \mathrm{~L}$ of substrate made up of subsoil and organic compost at the ratio of $3: 1(\mathrm{v} / \mathrm{v})$, which is equivalent to about $20.0 \mathrm{t} \mathrm{ha}^{-1}$ of organic compost at planting, and supplemented with simple superphosphate $\left(5 \mathrm{~kg} / \mathrm{m}^{3}\right.$ substrate). The compost was produced in piles, using mature napier grass clippings and poultry litter with wood shavings at the ratio of $3.5: 1(\mathrm{v} / \mathrm{v})$. Table 1 shows the nutrient levels in the poultry litter and the compost. Nutrient contents in the soil used to make the substrate were: $\mathrm{P}=2.7$ $\mathrm{mg} \mathrm{dm}{ }^{-3}, \mathrm{~K}=8 \mathrm{mg} \mathrm{dm}^{-3}, \mathrm{Ca}^{2+}=0.6 \mathrm{cmol} \mathrm{dm} \mathrm{dm}^{-3} ; \mathrm{Mg}^{2+}=0.3$ $\mathrm{cmol}_{\mathrm{c}} \mathrm{dm}^{-3}$ and $\mathrm{Al}^{3+}=0.5 \mathrm{cmol}_{\mathrm{c}} \mathrm{dm}^{-3}$, with $\mathrm{pH}\left(\mathrm{H}_{2} \mathrm{O}\right)=5.6$. The nutrient contents were determined by the following methods: $\mathrm{Ca}, \mathrm{Mg}$ and $\mathrm{Al}$ using the extractor $1 \mathrm{~mol} . \mathrm{L}^{-1} \mathrm{KCl}$; $\mathrm{P}$ and $\mathrm{K}$ with the Mehlich I; extractable acidity $(\mathrm{H}+\mathrm{Al})$ with the extractor SMP; and the $\mathrm{pH}$ in water at the ratio 1:2.5 (soil: water).

After seedling establishment, the top-dressing fertilization treatments were applied as follows: T1 (no top-dressing); T2 (mineral fertilization corresponding to $150.0 \mathrm{~kg} \mathrm{ha}^{-1} \mathrm{~N}, 240.0 \mathrm{~kg} \mathrm{ha}^{-1} \mathrm{~K}_{2} \mathrm{O}$ and $400.0 \mathrm{~kg} \mathrm{ha}^{-1} \mathrm{P}_{2} \mathrm{O}_{5}$ in three applications at 30, 45 and 60 days after transplanting); T3 (green manure equivalent to $5.0 \mathrm{t} \mathrm{ha}^{-1}$ gliricidia biomass (dry matter - DM) applied on the soil surface (without incorporation) at 10 days after transplanting); T4 (2.5 $\mathrm{t} \mathrm{ha}^{-1}$ gliricidia biomass (DM) applied at 10 days after transplanting); T5 (2.5 t ha-1 gliricidia biomass (DM) applied at 10 days after transplanting + application of liquid biofertilizer of cattle manure diluted in water at the ratio of 1:1 corresponding to $2.0 \mathrm{~L} \mathrm{~m}^{-2}$ applied at $30,37,45,52$ and 60 days after transplanting); T6 (2.5 $\mathrm{t} \mathrm{ha}^{-1}$ gliricidia biomass (DM) applied at 10 days after transplanting + surface application of Bokashi corresponding to $\left.150 \mathrm{~g} \mathrm{~m}^{-2}\right)$; $\mathrm{T} 7$ (2.5 $\mathrm{t} \mathrm{ha}^{-1}$ gliricidia biomass (DM) applied at 10 days after transplanting $+2.0 \mathrm{~L} \mathrm{~m}^{-2}$ of liquid biofertilizer of cattle manure diluted in water at the ratio of 1:1 applied at 30, 37, 45, 52 and 60 days after transplanting $+150 \mathrm{~g} \mathrm{~m}^{-2}$ Bokashi); and T8 (planting substrate made of subsoil + raw poultry litter (non composted) at the ratio of $3: 1(\mathrm{v} / \mathrm{v})$, supplemented with simple superphosphate at $5 \mathrm{~kg} \mathrm{~m}^{-3}$ substrate). Treatment T8 differed from the others by replacing the organic compost by the non-composted poultry litter in the substrate, which is the form commonly used by farmers in fertilization, because composting of poultry litter is a labor-and time-consuming process. The experiment was arranged in a completely randomized design with eight treatments, four replications and two plants per experimental unit.

Table 1 shows the nutrient contents found in the poultry litter, liquid bio-fertilizer of cattle manure, Bokashi and the organic compost used in the experiment. Gliricidia biomass was obtained from adult plants grown from live stakes, in the Sector of Fruit Crops of UFV. Gliciridia dry matter content was determined by drying samples at 65 ${ }^{\circ} \mathrm{C}$ in an oven to a constant weight (about $72 \mathrm{~h}$ ). The liquid biofertilizer of cattle manure was produced in a 200 L plastic drum by mixing $90 \mathrm{~L}$ of fresh cattle manure with $90 \mathrm{~L}$ of water. The drum was kept sealed tightly for 60 days. A vent system was adapted to the drum lid (a hose coming out of the drum lid with the lower end immersed in a container with water) to allow the methane gas produced during the fermentation to exit the drum, without the entry of oxygen (anaerobic fermentation).

Table 1. Nutrient contents** in the organic fertilizers used in the experiment

\begin{tabular}{lcccccccccccc}
\hline \multirow{2}{*}{ Fertilizer* } & $\mathbf{N}$ & $\mathbf{P}$ & $\mathbf{K}$ & $\mathbf{C a}$ & $\mathbf{M g}$ & $\mathbf{S}$ & & $\mathbf{Z n}$ & \multicolumn{2}{c}{$\mathbf{F e}$} & $\mathbf{M n}$ & $\mathbf{C u}$ \\
\hline GB & 4.23 & 0.19 & 2.20 & 1.09 & 0.24 & 0.18 & & 19 & 156 & 34 & 5 \\
BK & 0.74 & 0.24 & 0.47 & 1.35 & 0.24 & 0.69 & & 58 & 3004 & 432 & 24 \\
BCM & 0.41 & 0.02 & 0.21 & 0.21 & 0.05 & 0.02 & & 2. & 22 & 7 & 1 \\
PL & 2.81 & 8.28 & 3.82 & 2.21 & 1.05 & 1.29 & & 10 & 21 & 12 & 2 \\
CO & 1.68 & 4.58 & 1.81 & 4.67 & 0.83 & & 0.63 & & 5 & 0.000 & 15 & 1 \\
\hline
\end{tabular}

* GB - Gliricidia biomass; BK - Bokashi; BCM - Biofertilizer of cattle manure; PL - Poultry litter (non-composted); CO - Compost of poultry litter and napier grass.** $\mathrm{N}$ concentration was determined after sulfuric digestion by the Kjedahl method. Contents of $\mathrm{P}, \mathrm{K}, \mathrm{Ca}, \mathrm{Mg}$ and $\mathrm{S}$ were determined after nitric-perchloric digestion. $\mathrm{P}$ was determined based on the formation of a complex between phosphate and sodium molybdate in the presence of ascorbic acid as the reducing agent. $\mathrm{K}$ was determined by flame photometry and $\mathrm{Ca}$ and $\mathrm{Mg}$ by atomic absorption spectrophotometry. 
Bokashi was produced from a mixture of $60 \mathrm{~L}$ of forest humus (litter), $120 \mathrm{~L}$ of cattle manure, $120 \mathrm{~L}$ of rice husk, 60 L charcoal dust, $30 \mathrm{~kg}$ of wheat meal, $2.0 \mathrm{~kg}$ of molasses and $50 \mathrm{~L}$ of water (enough to the mixture reached about $50 \%$ moisture). The materials were mixed using shovels and hoes, forming a small heap that was covered with burlap sacks. The fermentation process was controlled by monitoring the temperature inside the mixture and by turning it when the temperature reached $50{ }^{\circ} \mathrm{C}$ (Adapted from Trivellato, 2002).

The production of commercial broccoli inflorescences $\left(\mathrm{t} \mathrm{ha} \mathrm{h}^{-1}\right)$ was evaluated for each treatment. Data were subjected to analysis of variance by $\mathrm{F}$ test and means were compared by Dunnett's test at $5 \%$ probability $(\mathrm{P}<0.05)$.

\section{RESULTS AND DISCUSSION}

Only the treatment $\mathrm{T} 5$ (2.5 $\mathrm{tha}^{-1}$ gliricidia biomass (DM) $+2.0 \mathrm{~L} \mathrm{~m}^{-2}$ biofertilizer at 50\%, applied at 30, 37, 45, 52 and 60 days after transplanting) provided yield of commercial inflorescences higher than the control treatment T1 (20 t $\mathrm{ha}^{-1}$ of organic compost at planting) (Figure 1).

Plants that received the treatment $\mathrm{T} 5\left(2.5 \mathrm{tha}^{-1}\right.$ gliricidia biomass $(\mathrm{DM})$ at 10 days after transplanting $+2.0 \mathrm{~L} \mathrm{~m}^{-2}$ biofertilizer at $50 \%)$ also had yields $(\mathrm{P}<0.05)$ similar to those that received mineral fertilizers (Figure 2). The other organic fertilization treatments provided yields lower than the chemical fertilization.

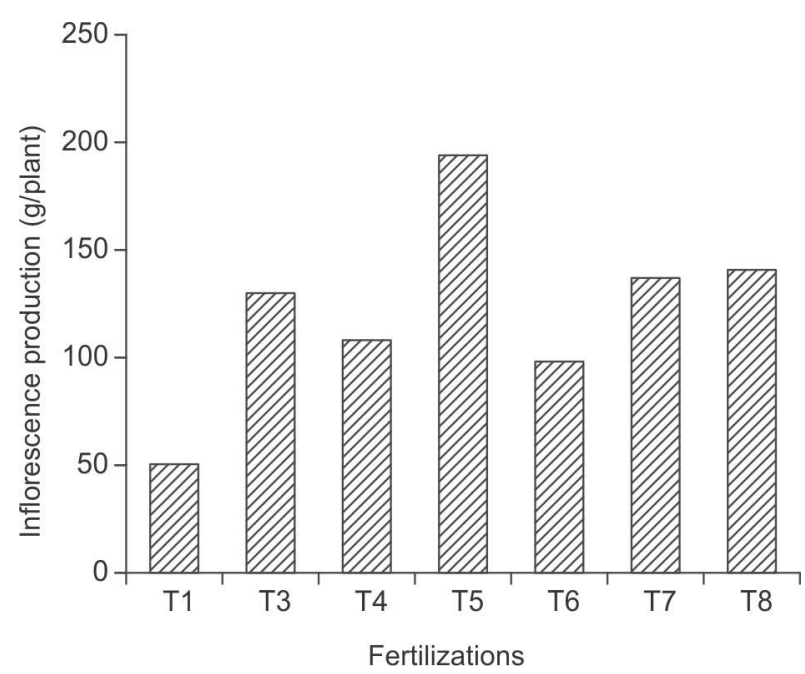

Figure 1. Comparison of means of the production of commercial broccoli inflorescences under top-dressing of different organic fertilizations.

Top-dressing fertilizations: T1 (no top-dressing); T3 (5.0 t ha-1 gliricidia biomass - DM); T4 (2.5 t ha ${ }^{-1}$ gliricidia biomass - DM); T5 (2.5 $\mathrm{t} \mathrm{ha}^{-1}$ gliricidia biomass $-\mathrm{DM}+2.0 \mathrm{~L} \mathrm{~m}^{-2}$ of biofertilizers at 50\%); T6 (2.5 t ha-1 gliricidia biomass - DM + $150 \mathrm{~g} \mathrm{~m}^{-2}$ Bokashi); $\mathrm{T} 7\left(2.5 \mathrm{t} \mathrm{ha}^{-1}\right.$ gliricidia biomass $-\mathrm{DM}+2.0 \mathrm{~L} \mathrm{~m}^{-2}$ of biofertilizer at $50 \%+150 \mathrm{~g} \mathrm{~m}^{-2}$ Bokashi) and T8 (only raw poultry litter at planting). Means with letters different from the treatment T1 are significantly different by the Dunnett's test at $1 \%$ probability level.
The superiority of the treatment T5 over the other organic fertilizations can be related to the combined use of legume biomass with the liquid biofertilizer of cattle manure. In this case, the gliricidia biomass would release nutrients gradually, while the biofertilizer, considered an organic fertilizer with nutrients readily available, would supplement the plants. The application of biofertilizers to the soil for the production of yellow passion fruit and papaya also provided positive effects on production and fruit quality (Mesquita et al., 2007; Araújo et al., 2008).

In the treatment $\mathrm{T} 7\left(2.5 \mathrm{t} \mathrm{ha}^{-1}\right.$ gliricidia $(\mathrm{DM})+2.0 \mathrm{~L} \mathrm{~m}^{-2}$ biofertilizer at $50 \%+150 \mathrm{~g} \mathrm{~m}^{-2}$ Bokashi), the addition of Bokashi to the treatment T5 resulted in lower yield. It is likely that the use of forest humus (leaf litter) in the production of Bokashi influenced negatively the broccoli production by immobilization of nutrients. Bokashi consists of a diverse and active microflora, because it is produced using inoculants based on efficient microbes (EM's) or forest soil. However, when it is made from forest soil, there is no guarantee that the microbial flora is effective for the target crop and environment. Della Bruna et al. (1991) showed that the addition of leaf litter can increase about five times the biological activity in soils. Assis Júnior et al. (2003) evaluated the non-instantaneous biological activity by the total amount of $\mathrm{CO}_{2}$ released during the decomposition of organic matter in the field. The systems native forest $\left(559.37 \mathrm{mg} \mathrm{m}^{-2} \mathrm{~h}^{-1} \mathrm{CO}_{2}\right)$, pasture

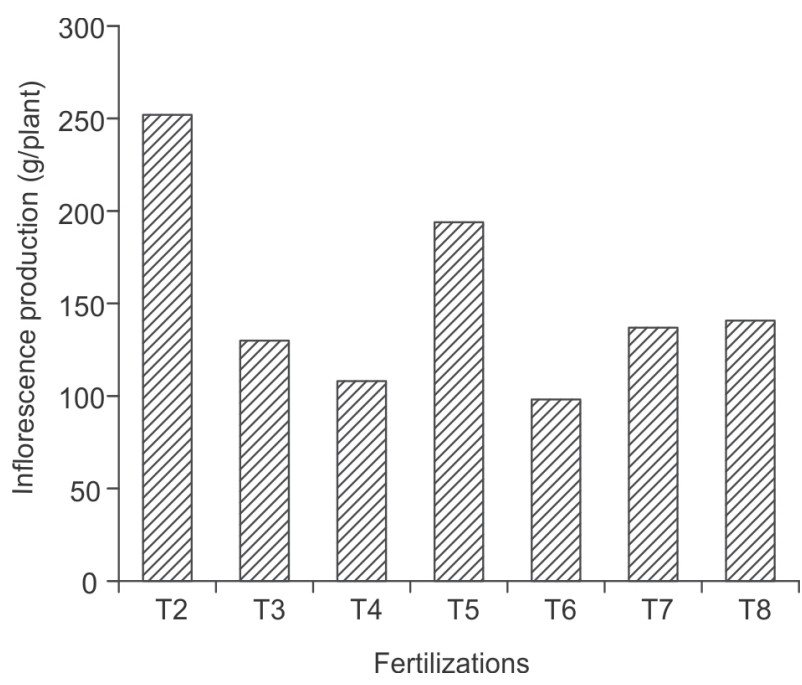

Figure 2. Comparison of production means of commercial broccoli inflorescences under top-dressing of different organic fertilizations.

Top-dressing fertilizations: T2 (150.0 kg ha-1 $\mathrm{N} ; 240.0 \mathrm{~kg} \mathrm{ha}^{-1} \mathrm{~K}_{2} \mathrm{O}$ and $400.0 \mathrm{~kg} \mathrm{ha}^{-1} \mathrm{P}_{2} \mathrm{O}_{5}$ ); T3 (5.0 $\mathrm{t} \mathrm{ha}^{-1}$ gliricidia biomass - DM); T4 (2.5 $\mathrm{t} \mathrm{ha}^{-1}$ gliricidia biomass - DM); T5 (2.5 $\mathrm{t} \mathrm{ha}^{-1}$ gliricidia biomass - DM + 2.0 $\mathrm{L} \mathrm{m}^{-2}$ of biofertilizers at 50\%); T6 (2.5 t ha ${ }^{-1}$ gliricidia biomass - DM + $150 \mathrm{~g} \mathrm{~m}^{-2}$ Bokashi); $\mathrm{T} 7$ (2.5 $\mathrm{t} \mathrm{ha}^{-1}$ gliricidia biomass - DM + 2.0 $\mathrm{L} \mathrm{m}^{-2}$ of biofertilizer at $50 \%+150 \mathrm{~g} \mathrm{~m}^{-2}$ Bokashi) and T8 (only raw poultry litter at planting). Means with letters different from the treatment T2 are significantly different by the Dunnett's test at $5 \%$ probability level. 
in monoculture (538.25 $\mathrm{mg} \mathrm{m}^{-2} \mathrm{~h}^{-1} \mathrm{CO}_{2}$ ) and pasture associated with eucalyptus (488.81 $\mathrm{mg} \mathrm{m}^{-2} \mathrm{~h}^{-1} \mathrm{CO}_{2}$ ) had higher biological activity, whereas the lowest values were recorded in rice $\left(202.82 \mathrm{mg} \mathrm{m}^{-2} \mathrm{~h}^{-1} \mathrm{CO}_{2}\right)$ and deforested areas $\left(165.16 \mathrm{mg} \mathrm{m}^{-2} \mathrm{~h}^{-1} \mathrm{CO}_{2}\right)$.

In a microbiological analysis of Bokashi, Magrini et al. (2009) found that yeasts were the most representative group, followed by bacteria and fungi. The fungi identified in the final stage of maturation of the compost belonged to different genera, especially Aspergillus sp., Dactylium sp. and Rhizopus sp.. Factors such as diversity of microbiota, availability of organic carbon sources and parameters such as the C/N/P and the lignocellulosic index affect soil biological activity (Assis Júnior et al., 2003).

Plants that received only Gliricidia biomass as topdressing, regardless of the rate tested (T3 and T4), had lower yields than those fertilized with mineral fertilizers. Salcedo \& Menezes (2007) also reported lack of effect for addition of gliricidia to corn production, using rates equivalent to those in this experiment. Although the gliricidia biomass has a low $\mathrm{C} / \mathrm{N}$ ratio, it takes some time for mineralizing nutrients and making them available to the crop (Marin et al., 2006). Therefore, its surface application, in a short cycle crop such as broccoli, has certainly not been enough to release the amount of nutrients necessary for the development of the crop.

Plants from the treatment T8 (substrate made of subsoil + raw poultry litter at the ratio of $3: 1(\mathrm{v} / \mathrm{v})$, without topdressing) also had lower yields than those fertilized with mineral fertilizers (Figure 2). This result showed that the replacement of the organic compost by poultry litter at planting did not reduce the need for top-dressing fertilization, since this treatment did not achieve the yields provided by T2 (mineral fertilization) or T5 (gliricidia biomass + liquid biofertilizer), which were $4.7 \mathrm{t} \mathrm{ha}^{-1}$ and 3.6 $t \mathrm{tha}^{-1}$ respectively. The use of biofertilizer applied to the soil in addition to cattle manure increased the production of peppers in comparison with the treatment that received only cattle manure (Araújo et al., 2007). Different rates of organic compost (5-25 $\left.\mathrm{t} \mathrm{ha}^{-1}\right)$ used in the production of broccoli provided yields from 6.67 to $12.5 \mathrm{t} \mathrm{ha}^{-1}$ (Diniz et al., 2008). Top-dressing of velvet bean, at the rates $0-12 \mathrm{t}$ $\mathrm{ha}^{-1}$, in addition to $12.5 \mathrm{t} \mathrm{ha}^{-1}$ of organic compost provided broccoli yields between $8.8 \mathrm{tha}^{-1}$ and $13.8 \mathrm{t} \mathrm{ha}^{-1}$ (Siqueira et al., 2009). The yield obtained in this study was lower than those achieved in these studies, which were conducted in the field, whereas this experiment was conducted in pots, which certainly restricted the volume of soil being explored by the plant root system. Besides, the fertilizer rates used in this experiment were lower, because the objective was a qualitative assessment, comparing the different types of organic fertilizers.

\section{CONCLUSIONS}

Organic fertilization at planting corresponding to $20 \mathrm{tha}^{-1}$ of organic compost of poultry litter is not enough to provide good production yields of commercial broccoli inflorescences.

Organic fertilization top-dressing with Gliricidia biomass associated with liquid biofertilizer of cattle manure applied to the soil result in production of broccoli inflorescences similar to those obtained by plants fertilized with mineral fertilizers.

The use of Bokashi made with forest topsoil in the production of broccoli reduce the efficiency of topdressing with Gliricidia biomass associated with liquid biofertilizer of cattle manure.

Top-dressing with only gliricidia biomass at the rates of $2.5 \mathrm{tha}^{-1}$ and $5.0 \mathrm{t} \mathrm{ha}^{-1}$ (DM) do not provide significant increases in the production of commercial broccoli inflorescences.

\section{REFERENCES}

Araújo EN, Oliveira AP, Cavalcante LF, Pereira WE, Brito NM, Neves CM \& Silva, EE (2007) Produção do pimentão adubado com esterco bovino e biofertilizante. Revista Brasileira de Engenharia Agrícola e Ambiental, 11:466-470.

Araújo DL, Alvesa AS, Andrade R \& Santos JGR (2008) Comportamento de maracujazeiro amarelo (Passiflora edulis f. sims flavicarpa deg) sob diferentes dosagens de biofertilizante e intervalos de aplicação. Revista Verde, 3:98-109.

Assis Júnior SL, Zanuncio JC, Kasuya MCM, Couto L \& Melido RCN (2003) Atividade microbiana do solo em sistemas agroflorestais, monoculturas, mata natural e área desmatada . Revista Árvore, 27:35-41 .

Cobo JG, Barrios E, Kass DCL \& Thomas R (2002) Nitrogen mineralization and crop uptake from surface-applied leaves of green manure species on a tropical volcanic-ash soil. Biology and Fertility of Soils, 36:87-92.

Della Bruna E, Borges AC, Fernandes B, Barros NF \& Muchovej RMC (1991) Atividade da microbiota de solos adicionados de serapilheira de eucalipto e de nutrientes. Revista Brasileira de Ciência do Solo, 15:15-20.

Diniz ER, Santos RH, Urquiaga S, Paternelli LA, Barrella TP \& Freitas GB (2008) Crescimento e produção de brócolis em sistema orgânico em função de doses de composto. Ciência e Agrotecnologia, 32:1428-1434.

Fontanetti A, Carvalho GJ, Gomes LAA, Almeida K, Moraes SRG \& Teixeira CM (2006) Adubação verde na produção orgânica de alface americana e repolho. Horticultura Brasileira, 24:146150 .

Handayanto E, Giller KE \& Cadisch, GR (1997) N release from legume tree prunings by mixing residues of different quality. Soil Biology and Biochemistry, 29:1417- 1426.

Lêdo FJS, Souza JA \& Silva MR (2000) Avaliação de cultivares e híbridos de repolho no Estado do Acre. Horticultura Brasileira, 18:138-140.

Lupwayi NZ \& Haque I (1999) Leucaena hedgerow intercropping and cattle manure application in the Ethipian highlands I. Decom position and nutrient release. Biology and Fertility of Soils, 28:182-195.

Rev. Ceres, Viçosa, v. 58, n.5, p. 645-650, set/out, 2011 
Magrini FE, Camatti-Sartori V \& Venturin L (2009) Avaliação Microbiológica, pH e Umidade de Diferentes Fases de Maturação do Biofertilizante Bokashi. In: VI Congresso Brasileiro e II Congresso Latino Americano de Agroecologia, Curitiba, Anais, ABA/SOCLA, p. 278-282.

Marin AMP (2006) Efeito da Gliricidia sepium sobre nutrientes do solo, microclima e produtividade do milho em sistema agroflorestal. Revista Brasileira de Ciência do Solo, 30:555564.

Menezes RSC \& Salcedo IH (2007) Mineralização de N após incorporação de adubos orgânicos em um Neossolo Regolítico cultivado com milho. Revista Brasileira de Engenharia Agrícola e Ambiental, 11:361-367.

Mesquita EF, Cavalvante LF, Gondim SC, Cavalcante IHL, Araújo FAR \& Beckmann-Cavalcante MZ (2007) Produtividade e qualidade de frutos do mamoeiro em função de tipos e doses de biofertilizantes. Semina: Ciências Agrárias, 28:589-596.

Oliveira FL, Ribas RGT, Junqueira RM, Padovam MP, Guerra JGM, Almeida DL \& Ribeiro RLD (2005) Desempenho do consórcio entre repolho e rabanete com pré- cultivo de crotalária, sob manejo orgânico. Horticultura Brasileira, 23:184-188.

Palm CA \& Sanchez PA (1991) Nitrogen release from the leaves of some tropical legumes as affected by their lignin and polyphenolic contents. Soil Biology and Biochemistry, 23:83-88.
Raij, BV (1969) A capacidade de troca de cátions das frações orgânica e mineral em solos. Boletim Científico do Instituto Agronômico do Estado de S. Paulo, 28:85-112.

Silva, VV (2002) Efeito do pré- cultivo de adubos verdes na produção orgânica de brócolos (Brassica oleraceae var. itálica) em sistema de plantio direto. Dissertação de Mestrado. Universidade Federal Rural do Rio de Janeijro, Seropedica, 86p.

Siqueira RG, Santos RH, Perigolo D, Urquiaga S, Ribas RGT \& Peternelli LA (2009) Nutrição nitrogenada e produção de brócolis cultivado com diferente doses de mucuna em duas épocas. Revista Ceres, 56:826-833.

Van Kessel JS \& Reeves JB (2002) Nitrogen mineralization potential of dairy manures and its relationship to composition. Biology and Fertility of Soils, 36:118-123.

Vitousek PM, Naylor R, Crews T, David MB, Drinkwater LE, Holland E, Johnes PJ, Katzenberger J, Martinelli LA, Matson PA, Nziguheba G, Ojima D, Palm CA, Robertson GP, Sanchez PA, Townsend AR \& Zhang FS (2009) Nutrient Imbalances in Agricultural Development. Science, 324:1519-1520.

Whalen JK, Chang C \& Olson BM (2001) Nitrogen and phosphorus mineralization potentials of soils receiving repeated annual cattle manure applications. Biology and Fertility of Soils, 34:334341 . 